\title{
Vanskelige prioriteringer
}

I dette nummer av Tidsskriftet har Bentdal og medarbeidere en artikkel om tarm- og flerorgantransplantasjon ved kronisk tarmsvikt (1). Da jeg fikk forespørsel om å skrive en leder relatert til denne artikkelen, svarte jeg at emnet nok var noe på siden av det jeg behersket. Hva i all verden vet vel en nevrokirurg om avansert transplantasjonsmedisin? Svært lite. Men så viste det seg altså at redaksjonen ønsket en generell kommentar om avansert behandling av små pasientgrupper, og da behøver man kanskje ikke være ekspert på transplantasjonsmedisin for å si noe om de prinsipielle sidene ved slik avansert behandling.

Artikkelen viser at dette er en spesielt sjelden, vanskelig og ressurskrevende transplantasjonsvirksomhet. Bare sju pasienter ble operert (i utlandet) i perioden 2001-09, og av dem overlevde bare fire. Prisen er høy. La dette være utgangspunkt for mine betraktninger.

Dessverre spriker disse betraktningene, og jeg har to motstridende tanker i hodet. På den ene side: Dette er allerede et etablert tilbud, men kan det forsvares å drive en slik dyr og avansert behandling med såpass høy mortalitet for noen ganske få? Og er det lov å spørre om dette er «regningssvarende»? På den annen side: Vi er jo opplært til å flytte grenser og mener at faget vil stagnere dersom vi ikke gjør det.

Hvor mye mer helse får vi ut av økte investeringer i helsevesenet? Vi har vel alle en forestilling om at sammenhengen mellom helse og investeringer i helse kan fremstilles som en asymptotisk kurve med grad av helse i befolkningen langs y-aksen og investeringer i helsevesenet langs $\mathrm{x}$-aksen. Så lenge et land befinner seg langt til venstre på kurven, vil selv små investeringer føre til vesentlige forbedringer. Norge ligger langt ute til høyre på kurven, og store investeringer fører etter hvert bare til marginalt bedret totalhelse. Som Hjalmar «Hjallis» Andersen skal ha sagt da han etter sin legendariske verdensrekord på Hamar (16.32.6) ble spurt om hvor langt ned man kunne presse rekordene: «Æ kan itj gå på null, sjø.» Tilsvarende vil vi aldri kunne nå en folkehelse på $100 \%$ - det skulle jo innebære at vi klarer å kurere alle sykdommer hele tiden og følgelig at ingen dør - noen gang. Én ting er sikkert - vi skal alle dø. Det vi som leger gjør er jo bare å utsette døden. Før eller senere er det slutt. Vår motivasjonen for dette utsettende arbeidet er vel at vi tror innsatsen er til det beste for våre medmennesker, at «det er verdt det».

Hvor går grensen - og hvem skal bestemme? Utgiftene til helse i vårt land har ligget stabilt på ca. $9 \%$ av bruttonasjonalproduktet de siste ti årene (2). Det har vi kanskje råd til, selv om jeg ikke egentlig tror at noen har forsøkt å beregne om «det er verdt det». Det er vanskelig å se noen naturlig grense for hvor mye vi kan klare å bruke til helse. For å sette det på spissen: Høyspesialiserte leger vil presse på for økte bevilgninger motivert av de faglige utfordringene, mens det ser ut til at politikere ikke tør å ta støyten med å sette begrensninger - fordi de er redde for å bli karakterisert som kalde og ufølsomme. Når noen fornuftig nok tar til orde for at «nok er nok» (3), vekker dette følelser og protester - fordi problemet plutselig og uvegerlig blir knyttet til identifiserbare personer.

All helsestatistikk består av tall. «Problemet» består i at det bak tallene skjuler seg mennesker og at vi jo stort sett er snille og godhjertede og gjerne vil gjøre alt vi kan når ulykken rammer våre medmennesker. Når problemet personifiseres, smelter vi. Jeg har de siste ti årene vært engasjert i spesialistutdanning i nevrokirurgi i Etiopia, et av verdens fattige land. Ut fra beregninger fra andre land i Afrika (4), vet vi at 3000-6 000 etiopiske spedbarn får hydrocephalus (vannhode) hvert år. Av disse får bare noen få hundre tilbud om behandling med gode utsikter til et normalt liv. Resten går til grunne og blir en enorm byrde for familien så lenge de lever, kanskje i mange år. Intellektuelt vet jeg at det bak hvert tall i statistikken ligger en tragedie for barnet og familien, men jeg klarer ikke å ta det ordentlig innover meg. Disse barna og deres familier er bare et tall som det er lett å la være å forholde seg til - så lenge jeg slipper å møte dem. Straks familien sitter der på poliklinikken med fortvilte og håpefulle ansikter, kanskje etter en dagsreise eller to, blir det umulig å opprettholde den intellektuelle tilnærmingen. Det er vel tilsvarende mekanismer som gjør det så vanskelig å sette grenser i medisinen.

Vi lever i overflod i vårt land. De av oss som ble født den gang Norge var blant de fattige landene i Europa, har vokst opp med formaninger om å spise opp maten - «tenk på de sultne barna i Afrika». Kan man i det hele tenke slik? Ville det ha hjulpet de sultende barna i Afrika at vi spiste opp maten vår? Tilsvarende kan vi spørre: Påvirker vår ressursbruk i vårt helsevesen utviklingen av helsetilbudet i utviklingsland? På grunn av den raske medisinskteknologiske utvikling i Vesten blir gapet mellom oss og u-landene stadig større - og gapet kan ikke tettes nedenfra, til det er disse landenes økonomi altfor svak. Hjelper det da dem at vi legger restriksjoner på oss selv? Presser vi «markedet» ved vår stadige forbedring av helsetilbudet slik at u-landene ikke klarer å følge oss? Avansert vestlig medisin lokker og fører til hjerneflukt. Våre utdanningskandidater i Etiopia er helt klare på at dette er et stort problem, men heldigvis ikke altoverskyggende. Enn så lenge er de unge og optimistiske og overbevist om at bare det faktum at de er i stand til å bedre helsetilbudet i landet sitt er viktigere enn at Vesten stadig drar fra dem. På lang sikt er jeg redd for at gapet mellom oss og dem vil føre til ytterligere utarming, blant annet fordi de beste vil fristes av de mulighetene vestlig avansert medisin kan tilby.

\section{Knut Wester \\ kgwe@helse-bergen.no}

Knut Wester (f. 1940) er professor emeritus ved Institutt for kirurgiske fag, Universitetet i Bergen, og tidligere avdelingsoverlege ved Nevrokirurgisk avdeling, Haukeland universitetssykehus. De siste ti årene har han vært engasjert i opprettelse og drift av et utdanningsprogram for nevrokirurger i Etiopia.

Forfatter har fylt ut ICMJE-skjemaet og oppgir ingen interessekonflikter

\section{Litteratur}

1. Bentdal $\emptyset \mathrm{H}$, Foss A, Østensen AB et al. Tarm- og flerorgantransplantasjon ved kronisk tarmsvikt. Tidsskr Nor Legeforen 2012; 132: 650-4.

2. Statistisk sentralbyrå. Helseregnskap 1997-2009. Helseutgiftene fortsetter å øke. www.ssb.no/helsesat/ (11.3.2012).

3. Westerveld J. Dette er så vondt å snakke om at det er blitt tiet ned i lang tid. Men nå må vi være ærlige. Aftenposten 4.6.2010. www.aftenposten.no/helse/ article3680095.ece (11.3.2012).

4. Warf BC; East African Neurosurgical Research Collaboration. Pediatric hydrocephalus in East Africa: prevalence, causes, treatments, and strategies for the future. World Neurosurg 2010; 73: 296-300. 